\title{
Bacterial Identification and Detection of Equol in Korean Soybean Paste
}

\author{
Seung-Gyun Woo ${ }^{1}$, So-Yeon Lee ${ }^{1}$, Go-Woon Choi $^{2}$, You-Jin Hong ${ }^{2}$, So-Min Lee ${ }^{2}$, Kang Gyun Park ${ }^{3}$, \\ and Yong-Bin Eom ${ }^{1,2}$ \\ ${ }^{1}$ Department of Medical Science, College of Medical Sciences, SoonChunHyang University, Asan 31538, Korea \\ ${ }^{2}$ Department of Biomedical Laboratory Science, College of Medical Sciences, SoonChunHyang University, Asan 31538, Korea \\ ${ }^{3}$ Department of Laboratory Medicine, Seoul St. Mary's Hospital, The Catholic University of Korea, Seoul 06591, Korea
}

\section{한국 된장에서 Equol의 검출 및 미생물 동정}

\author{
우승균 ${ }^{1}$, 이소연 ${ }^{1}$, 최고운 ${ }^{2}$, 홍유진 $^{2}$, 이소민 ${ }^{2}$, 박강균 $^{3}$, 엄용빈 ${ }^{1,2}$ \\ ${ }^{1}$ 순천향대학교 일반대학원 의료과학과, ${ }^{2}$ 순천향대학교 의료과학대학 임상병리학과, ${ }^{3}$ 서울성모병원 진단검사의학팀
}

\begin{abstract}
Equol has beneficial effects on human health. Fermented soy products contain equol, and many microbes participate in the equol production process. This study investigated fermented Korean soybean paste, doenjang. Thirty seven doenjang samples collected from different manufacturers were examined. Equol was detected in 3 samples (D2, D13, and D19) at the maximum content of $507 \mathrm{ng} / 100 \mathrm{~g}$ by liquid chromatography-tandem mass spectrometry (LC-MS/MS). Fifteen microbial species were isolated and identified by $16 \mathrm{~S}$ rRNA gene sequence analysis and by matrix assisted laser desorption/ionization-time of flight mass spectrometry (MALDI-TOF MS). Bacillus spp, Paenibacillus spp, Tetragenococcus spp, Stapylococcusspp, and Clostridium species were the predominant bacteria in equol containing doenjang samples.
\end{abstract}

Keywords: Equol, LC-MS/MS, MALDI-TOF mass spectrometry, $16 \mathrm{~S}$ rRNA gene sequence

This is an Open Access article distributed under the terms of the Creative Commons Attribution Non-Commercial License (http://creativecommons.org/licenses/by-nc/4.0) which permits unrestricted non-commercial use, distribution, and reproduction in any medium, provided the original work is properly cited.

Copyright @ 2015 The Korean Society for Clinical Laboratory Science. All rights reserved.
Corresponding author: Yong-Bin Eom Department of Biomedical Laboratory Science, College of Medical Sciences, SoonChunHyang University, Asan 31538, Korea Tel: 82-41-530-3039

E-mail:omnibin@sch.ac.kr

Received: July 30, 2015

Revised: $1^{\text {st: }}$ September 25, 2015

Revised: $2^{\text {nd. }}$ : October 17,2015

Revised: $3^{\text {rd: }}$ : October 21, 2015

Accepted: November 5, 2015

\section{Introduction}

Isoflavones are organic compounds found in plants including soybeans. They are referred to as phytoestrogens because they are structurally and functionally similar to estrogen, and have potentially beneficial effects on human health. Epidemiologic and experimental studies have indicated preventive effects on breast cancer, prostate cancer, cardio-vascular disease, and symptoms of osteoporosis and menopause (Adlercreutz, 2002).

Equol (4',7-dihydroxy-isoflavandiol) is a metabolite of daidzein, a major soybean isoflavone. Interest is increasing in equol due to its beneficial effects on human health (Sathyamoorthy \& Wang, 1997). Equol is converted via dihydrodaidzein to $O$-desmethylangolensin (O-DMA) or equol by enzymes of intestinal bacteria (Bowey et al., 2003).

The potent bioactivity of equol led to a boost of investigations in separation of the specific bacteria responsible for converting daidzein to equol. To date, several bacteria capable of producing equol have been separated from human or animal feces (Maruo et al., 2008; Matthies et al., 2008; Jin et al., 2010). Many bacteria that convert daidzein to equol have 
not been isolated from foods.

Stinky tofu, a traditional fermented soy food in Taiwan, is enriched in $S$-equol (Abiru et al., 2012; Jou et al., 2013). It has been assumed that equol-producing bacteria may be involved in equol production during the fermentation processes of stinky tofu.

Based on this background, we measured the equol contents in fermented Korean soybean pastes and identified bacteria using 16S rRNA gene sequence analysis and two matrix assisted laser desorption/ionization-time of flight mass spectrometry (MALDI-TOF MS), using a Bruker Microflex MS (BMS) and VITEK MS (VMS) systems (Kim et al. 2015).

\section{Materials and Methods}

\section{Chemicals}

The reference standard, $S$-equol was purchased from Cayman (Ann Arbor, MI, USA). High-pressure liquid chromatography (HPLC) grade methanol and acetonitrile (ACN) were purchased from J.T. Baker (Phillipsburg, NJ, USA). Formic acid (liquid chromatography-MS grade) and HPLC grade dimethyl sulfoxide (DMSO) were purchased from Sigma-Aldrich (St. Louis, MO, USA). All other chemicals were analytical grade quality and all solvents were HPLC grade.

\section{Sample preparation and extraction}

Thirty seven doenjang samples (D1 to D37) made using the traditional Korean process were collected from manufacturers and immediately stored at $-20^{\circ} \mathrm{C}$. On the day of the analysis, the sample was thawed at room temperature and approximately $1 \mathrm{~g}$ of sample was added to $10 \mathrm{~mL}$ methanol and mixed on a vortex mixer until a homogenous sample was obtained. The mixture was sonicated for $15 \mathrm{~min}$ and $2 \mathrm{~mL}$ aliquots were centrifuged at $12,000 \mathrm{rpm}$ for $10 \mathrm{~min}$ at $4^{\circ} \mathrm{C}$ to precipitate proteins. Aliquots of the supernatant $(1.5 \mathrm{~mL})$ were individually transferred to $2.0 \mathrm{~mL}$ tubes and placed in a vacuum concentrator. The dried residue was reconstituted in $0.1 \mathrm{~mL}$ of $50 \% \mathrm{ACN}$ by vortex mixing. After $10 \mathrm{~min}$ of sonication, the supernatant $(0.1 \mathrm{~mL})$ was extracted and loaded into a Costar Spin-X centrifuge tube filter $(0.22 \mu \mathrm{m}$; Nylon Corning Incorporated, Corning, NY, USA) and centrifuged at 3,000 rpm for $10 \mathrm{~min}$. The extract was transferred to HPLC-vials before injection in the liquid chromatography-tandem mass spectrometry (LC-MS/MS) device.

\section{LC-MS/MS instrumentation and analytical conditions}

Mass spectrometric detection was performed on a 3200 QTRAPR(AB Sciex, Foster City, CA, USA) using a hybrid triple quadrupole linear ion trap equipped with a TurboIonspray ion source and electrospray ionization (ESI) probe. The mass spectrophotometer was set at the negative mode. The parameters were: source temp $=600^{\circ} \mathrm{C}$, ion spray voltage $=$ $-4500 \mathrm{~V}$, declustering potential $=-30 \mathrm{~V}$, entrance potential $=$ $-4.5 \mathrm{~V}$, collision energy $=-28 \mathrm{~V}$, curtain gas $=25 \mathrm{psi}$, cad gas=medium, gas $1=55 \mathrm{psi}$, and gas2 $=55 \mathrm{psi}$ The data were processed using Analyst $\mathbb{R} 1.5$ version software. LC separations were performed by using a 1200 series HPLC apparatus (Agilent Technologies, Santa Clara, CA, USA). The HPLC module consisted of an Agilent 1200 series binary pump, Agilent 1200 series micro-vacuum degasser, and Agilent 1200 series autosampler. The analytes were chromatographed on a YMC Triart C18 column $(2.1 \mathrm{~mm} \times 100 \mathrm{~mm}$, S-3 $\mu \mathrm{m}, 12 \mathrm{~nm}$; YMC Co. Ltd., Kyoto, Japan) at a flow rate of $200 \mathrm{~mL} / \mathrm{min}$ with gradient elution of (0.05\% formic acid and $80+20 \%$ deionized water - acetonitrile) using the gradient steps (Table 1). The injection volume was $15 \mu \mathrm{L}$ and the autosampler was operated at room temperature.

\section{Isolation}

Doenjang samples were cultured on thioglycollate broth (BD, Heidelberg, Germany) for $16 \sim 24 \mathrm{~h}$ at $37^{\circ} \mathrm{C}$. After

Table 1. HPLC pump gradient elution of the equol for each run

\begin{tabular}{lcccc}
\hline Step & Time (min) & $\begin{array}{c}\text { Flow rate } \\
(\mathrm{mL} / \mathrm{min})\end{array}$ & $\begin{array}{c}\text { \%A } 0.05 \% \\
\text { FA in DI }\end{array}$ & $\begin{array}{c}\text { \%B } 0.05 \% \\
\text { FA in ACN }\end{array}$ \\
\hline Initial & 0 & 0.2 & 80 & 20 \\
2 & 2 & 0.2 & 80 & 20 \\
3 & 4 & 0.2 & 20 & 80 \\
4 & 6 & 0.2 & 20 & 80 \\
5 & 6.2 & 0.2 & 80 & 20 \\
6 & 9 & 0.2 & 80 & 20 \\
\hline
\end{tabular}

Abbreviation: FA, formic acid; DI, deionized water; ACN, acetonitrile. 
enrichment of the samples, the cultures were grown on blood agar plates for 16 24 $\mathrm{h}$ in a anaerobic condition provided by CampyGen (Becton Dickinson, GasPack) for isolating the organisms.

\section{MALDI-TOF VITEX MS (VMS) and BRUKER MS (BMS)}

VMS and BMS target slides were prepared according to the manufacturer's instructions. The resulting slides of VMS were analyzed in a VITEX MS device (bioMerieux) using the automatic database analysis of the obtained mass spectra within MYLA software (bioMerieux) to provide isolate identification. The results were evaluated according to a colored index: green for $\geq 90 \%$ identity, yellow for $85 \sim 89.9 \%$ identity, and white for $<85 \%$ identity. All of the identifications to the genus or species level fell into the green zone, with a score of $>90 \%$ considered reliable. Scores between 85 and $90 \%$ were considered as acceptable identification. A cut-off of $90 \%$ was chosen for the VITEX MS.

Measurements of BMS were done with a microflex LT mass spectrometer (Bruker Daltonics GmbH, Bremen, Germany) using flexControl ${ }^{\mathrm{TM}}$ software. The identification was provided by a score of reliability [A log (score) value between 0.00 and 3.00 was calculated : $<1.7=$ ID not reliable; $1.7 \leq$ and $<2.0=$ ID at genus level; $2.0 \leq=$ ID at species level]. A result was considered species consistent if all matches with a log score between 1.7 and 2.0 corresponded only to other species of the same genus. A genus consistent result was accepted if all $\log$ scores $1.7 \leq$ belong to the same genus.

Bacillus subtilis ATCC 6051 and Escherichia coli ATCC 8739 were included as positive controls and matrix alone with no organism was included as a negative control in each run in both MALDI-TOF systems. Discrepancies were defined as different genus- or species- level identification obtained from the VITEX MS, Microflex Bruker MS. Whenever there was a discrepancy, the analysis was repeated by both systems to eliminate the possibility of contamination. Thereafter, any other disagreements in the identification were resolved by performing 16S rRNA gene sequencing on the discrepant isolates.

\section{6. $16 \mathrm{~S}$ rRNA gene sequencing}

To prepare cells for DNA extraction, the cultivated strains were collected by centrifugation at $14,000 \times \mathrm{g}$ for $5 \mathrm{~min}$ at $4^{\circ} \mathrm{C}$. The resulting pellet was extracted using a QIAamp DNA minikit (Qiagen, Valencia, CA, USA). The extracted DNA was used as a PCR template for the amplification of 16S rRNA genes with the universal primer pair 5'-AGAGTTTGATCCTGGCTCAG-3' (27F) and 5'-GGCTACCTTGTTACGACTT-3' (1492R). The 16S rRNA gene was amplified by PCR with a thermal cycler (Applied Biosystems, Foster City, CA, USA). The amplified products were purified with a QIAquick PCR purification kit (Qiagen). The PCR products were sequenced using the ABI Big Dye v3.1 Terminator Ready Reaction Cycle Sequencing Kit (Applied Biosystems) using manufacturer's protocol. The samples were purified to remove excess salt and unincorporated dNTPs, denatured with HiDi-Formamide at $95^{\circ} \mathrm{C}$ for $3 \mathrm{~min}$, and analyzed using 3730 DNA Analyzer (Applied Biosystems). The obtained sequences were compared with sequences present in the GeneBank database (National Center for Biotechnology Information Bethesda, MD, U.S.A.) using BLAST software (http://www.ncbi.nih.gov).

\section{Results}

\section{Determination of equol by LC-MS/MS}

Equol contents of 37 doenjang samples collected in this study were determined by LC-MS/MS (Table 2). As shown in Fig. 1, the chromatographic retention time of standard solution, doenjang sample 2 (D2), doenjang sample 13 (D13), doenjang sample 19 (D19) was $5.52 \mathrm{~min}, 5.54 \mathrm{~min}, 5.52 \mathrm{~min}$, and $5.53 \mathrm{~min}$, respectively. Peak of equol was detected and the equol fraction contained a single peak with a retention time corresponding to that of the standard solution.

Relatively high concentrations were detected in the three samples (350 ng/100 g in D2, 507 ng/100 g in D13, and 368 $\mathrm{ng} / 100 \mathrm{~g}$ in D19) compared to the other samples. Equol was qualitatively determined by comparison with standard chromatogram and by doping the samples with standard reference. 


\section{Bacterial communities of doenjang samples}

Microbes in D2, D13, and D19 were isolated and identified. As shown in Table 3, both BMS and VMS correctly identified 1 Bacillus licheniformis, 1 Staphylococcus hominis, 1 Staphylococcus warneri, 1 Bacillus cereus, 1 Bacillus circulans to the species level. However, both systems misidentified Clostridium xylanolyticum as Clostridium clostridioforme and Clostridium aerotolerans, respectively.

BMS misidentified 1 Bacillus licheniformis as Bacillus

Table 2. Equol contents (ng/100 g) of 37 Doenjang samples

\begin{tabular}{cccc}
\hline Sample & Equol content & Sample & Equol content \\
\hline D1 & 4 & D19 & 368 \\
D2 & 350 & D20 & 10 \\
D3 & 52 & D21 & 187 \\
D4 & 98 & D22 & 128 \\
D5 & 238 & D23 & 27 \\
D6 & 123 & D24 & 248 \\
D7 & 77 & D25 & 12 \\
D8 & 39 & D26 & 11 \\
D9 & 10 & D27 & 207 \\
D10 & 104 & D28 & 80 \\
D11 & 57 & D29 & 37 \\
D12 & 95 & D30 & 29 \\
D13 & 507 & D31 & 107 \\
D14 & 234 & D32 & 44 \\
D15 & 22 & D33 & 113 \\
D16 & 28 & D34 & 69 \\
D17 & 54 & D35 & 80 \\
D18 & 53 & D36 & 46 \\
& & D37 & 4 \\
\hline
\end{tabular}

Abbreviation: D, Doenjang. sonorensis, 1 Bacillus amyloliquefaciens as Bacillus subtilis, 4 Bacillus subtilis as Bacillus amyloliquefaciens, 1 Tetragenococcus halophilus as Lactobacillus amylovorus compared to the sequencing results.

VMS misidentified 1 Paenibacillus odorifer as Bacillus
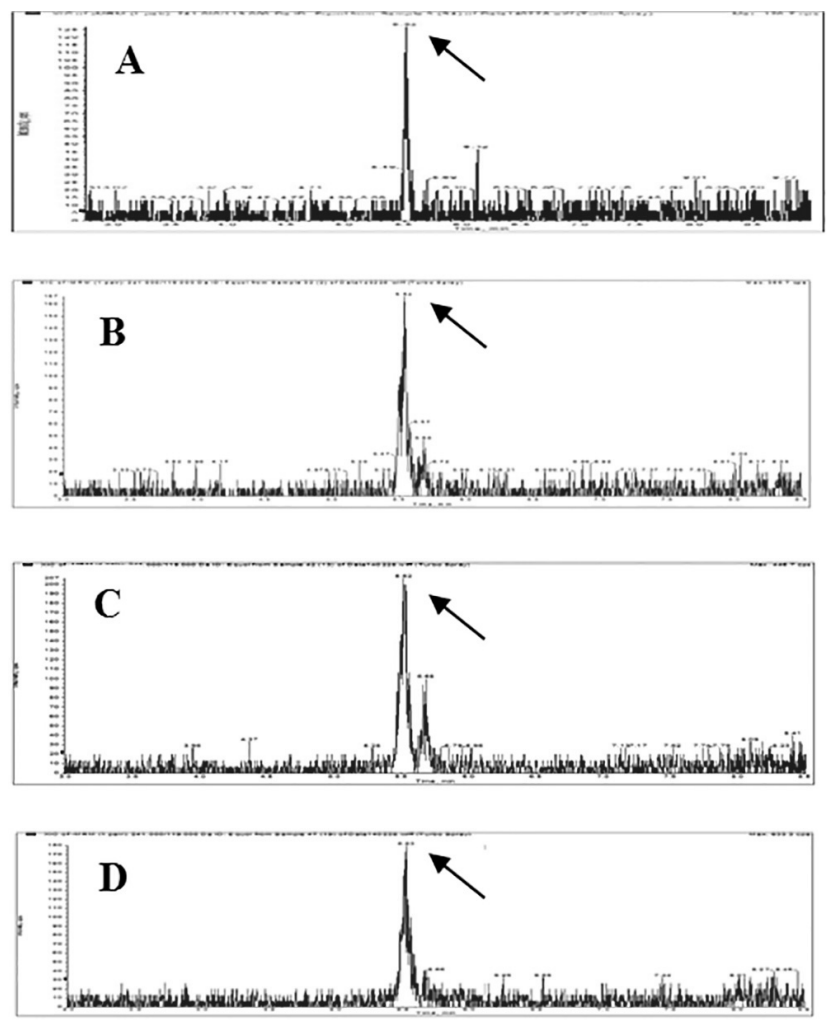

Fig. 1. Chromatographic retention time of: (A) Standard solution, (B) Doenjang sample 2 (D2), (C) Doenjang sample 13 (D13), (D) Doenjang sample 19 (D19). The peaks of equol are pointed by arrows.

Table 3. Bacterial identification of equol containing doenjang samples

\begin{tabular}{|c|c|c|c|}
\hline \multicolumn{2}{|c|}{ MALDI-TOF MS } & \multirow{2}{*}{$\begin{array}{l}16 \mathrm{~S} \text { rRNA } \\
\text { sequence results }\end{array}$} & \multirow{2}{*}{ Final identification } \\
\hline VITEX MS (VMS) & Bruker MS (BMS) & & \\
\hline Bacillus licheniformis & Bacillus licheniformis & & Bacillus licheniformis \\
\hline Bacillus licheniformis & Bacillus sonorensis & Bacillus licheniformis & Bacillus licheniformis \\
\hline Bacillus licheniformis & Paenibacillus odorifer & Paenibacillus odorifer & Paenibacillus odorifer \\
\hline Bacillus amyloliquefaciens & Bacillus subtilis & Bacillus amyloliquefaciens & Bacillus amyloliquefaciens \\
\hline Clostridium clostridioforme & Clostridium aerotolerans & Clostridium xylanolyticum & Clostridium xylanolyticum \\
\hline Bacillus subtilis (4) & Bacillus amyloliquefaciens (4) & Bacillus subtilis (4) & Bacillus subtilis (4) \\
\hline Staphylococcus hominis & Staphylococcus hominis & & Staphylococcus hominis \\
\hline Tetragenococcus halophilus & Lactobacillus amylovorus & Tetragenococcus halophilus & Tetragenococcus halophilus \\
\hline Staphylococcus warneri & Staphylococcus warneri & & Staphylococcus warneri \\
\hline Paenibacillus peoriae & Paenibacillus polymyxa & Paenibacillus polymyxa & Paenibacillus polymyxa \\
\hline Bacillus cereus & Bacillus cereus & & Bacillus cereus \\
\hline Bacillus circulans & Bacillus circulans & & Bacillus circulans \\
\hline
\end{tabular}

Discrepant results were resolved by $16 \mathrm{~S}$ rRNA gene sequencing. 
licheniformis, 1 Paenibacillus polymyxa as Paenibacillus peoriae. Clostridium clostridioforme and Clostridium aerotolerans were not present in its database but identified by $16 \mathrm{~S}$ rRNA sequencing as Clostridium xylanolyticum. Using 16S rRNA sequencing results as the reference standard, misidentified results from two different MALDI-TOF MS systems were confirmed. Their sequences showed more than 99\% identity with those of the GenBank database.

\section{Discussion}

Korean soy foods are increasingly present on the worldwide market. Fermented soybean paste, doenjang, was registered in CODEX on July 4, 2009, and is now an internationally accepted food (Yang et al., 2011). It is manufactured by soaking, steaming, and fermenting soybeans in a humid closed space maintained at $30^{\circ} \mathrm{C}$ for specific periods. Fermentation is one of the major processes used in the production of doenjang and many microbes participate in fermentation process.

It has been reported that stinky tofu, a traditional and popular fermented soy food, was found to be rich in equol and many microbes participated in equol production process (Abiru et al., 2012). Also, several studies showed that many types of isoflavones were detected in the fermented Korean soybean paste. To the best of our knowledge, there have been no investigations up till now regards equol contents of fermented Korean soybean paste. Based on these points, we hypothesized that fermented Korean soybean paste may contain equol contents. Organisms identified in equol containing doenjang samples will have differences compared with dominant organisms in normal doenjang (i, e., Bacillus subtilis, B. licheniformis) that play important roles during fermentation. The present study assessed this hypothesis.

The present analysis revealed a maximum equol content of 507 ng per $100 \mathrm{~g}$ doenjang. Four Bacillus subtilis, two Bacillus licheniformis, and one each of Paenibacillus odorifer, Bacillus amyloliquefaciens, Staphylococcus hominis, Clostridium xylanolyticum, Tetragenococcus halophilus, Staphylococcus warneri, Paenibacillus polymyxa, Bacillus cereus, and Bacillus circulans were identified in equol containing doenjang samples. Equol content in doenjang samples varied. The variation may reflect a number of factors, such as differences in the fermentation environment and/or the state of raw materials.

Limitations of this study were the relatively small number of samples and microbes identified in the current methods. The analyses of the diverse microbes in doenjang samples was limited because of the culture-dependent methods, which only identify isolated strains growing on specific nutrient media (Yoo et al., 1999). Addition to foods reported to contain equol, such as dairy and egg products (Antignac et al., 2004), the current study shows that fermented Korean soybean paste also contains equol and demonstrates that doenjang can be a good dietary source of equol. Additional studies will be needed to analyze diverse microorganisms that involved in equol containing doenjang samples by culture-independent analysis method in many doenjang samples.

In conclusion, fermented Korean soybean paste is a food that contains the equol, which we detected for the first time. The results demonstrate fermented Korean soybean paste served as a good dietary source of equol and it is of great interest to conduct further studies on identification of the specific equol-producing bacteria.

\section{요 약}

에쿠올은 인간의 건강에 유익한 효과를 나타낸다. 발효된 콩 식 품들은 에쿠올을 함유하고 있으며, 많은 미생물들이 에쿠올 생산 과정에 참여하는 것으로 밝혀졌다. 본 연구에서는 한국의 전통 발 효 식품인 된장에 대해 조사하였다. 먼저 서로 다른 제조자로부터 수집 된 37 개의 된장 샘플들을 대상으로 에쿠올의 농도를 측정하 기 위해 LC-MS/MS를 시행하였다. 측정 결과 3개의 된장 샘플에서 에쿠올이 검출되었고, $507 \mathrm{ng} / 100 \mathrm{~g}$ 의 농도가 가장 높게 나타났 다. 에쿠올을 함유한 된장에서 15 개의 미생물 종들이 $16 \mathrm{~S} \mathrm{rRNA}$ gene sequence analysis와 2개의 MALDI-TOF MS분석법에 의해 분리, 동정되었으며 Bacillus spp, Paenibacillus spp, Tetragenococcus spp, Stapylococcus spp, and Clostridium species들 이 가장 우세한 미생물들이었다. 이 연구결과로 한국의 전통 발효 식품인 된장에서도 에쿠올이 검출되었음을 확인하였다. 
Acknowledgements: This study was supported by Soonchunhyang University research fund, by Basic Science Research Program, through the National Research Foundation of Korea, funded by the Ministry of Education (NRF-2014R1A1A2A16055670) and by Laboratory Safety Management Program, through the National Research Foundation of Korea, funded by the Ministry of Science, ICT and Future Planning (NRF-2015M3B6A5022471).

Funding: None

Conflict of interest: None

\section{References}

1. Abiru Y, Kumemura M, Ueno T, Uchiyama S, Masaki K. Discovery of an S-equol rich food stinky tofu, a traditional fermented soy product in Taiwan. Int J Food Sci Nutr. 2012, 63:964-970.

2. Abiru Y, Ueno T, Uchiyama S. Isolation and characterization of novel S-equol-producing bacteria from brines of stinky tofu, a traditional fermented soy food in Taiwan. Int J Food Sci Nutr. 2013,64:936-943.

3. Adlercreutz H. Phyto-oestrogens and cancer. Lancet Oncol. 2002,3:364-373.

4. Antignac JP, Cariou R, Le Bizec B, André F. New data regarding phytoestrogens content in bovine milk. Food Chem. 2004, 87:275-281.

5. Bowey E, Adlercreutz H, Rowland I. Metabolism of isoflavones and lignans by the gut microflora: a study in germ-free and human flora associated rats. Food Chem Toxicol. 2003,41: 631-636.
6. Jin JS, Kitahara M, Sakamoto M, Hattori M, Benno Y. Slackia equolifaciens sp. nov., a human intestinal bacterium capable of producing equol. Int J Syst Evol Microbiol. 2010,60:1721-1724.

7. Jou HJ, Tsai PJ, Tu JH, Wu WH. Stinky tofu as a rich source of bioavailable S-equol in Asian diets. J Funct Foods. 2013,5:651659.

8. Kim SM, Sung JY, Choi SG. Molecular Characterization of Escherichia coli Isolates from Humans and Chickens in the Chungcheong Area Using MLST Analysis. Korean J Clin Lab Sci. 2015,47:71-77.

9. Maruo T, Sakamoto M, Ito C, Toda T, Benno Y. Adlercreutzia equolifaciens gen. nov., sp. nov., an equol-producing bacterium isolated from human faeces, and emended description of the genus Eggerthella. Int J Syst Evol Microbiol. 2008,58: 1221-1227.

10. Matthies A, Clavel T, Gütschow M, Engst W, Haller D, Blaut M, et al. Conversion of daidzein and genistein by an anaerobic bacterium newly isolated from the mouse intestine. Appl Environ Microbiol. 2008,74:4847-4852.

11. Sathyamoorthy N, Wang TTY. Differential effects of dietary phyto-oestrogens daidzein and equol on human breast cancer MCF-7 cells. Eur J Cancer. 1997,33:2384-2389.

12. Setchell KD, Clerici C, Lephart ED, Cole SJ, Heenan C, Castellani D, et al. S-equol, a potent ligand for estrogen receptor $\beta$, is the exclusive enantiomeric form of the soy isoflavone metabolite produced by human intestinal bacterial flora. Am J Clin Nutr. 2005,81:1072-1079.

13. Yang HJ, Kwon DY, Chung KR, Park S, Pak V. Fermented soybean products and their bioactive compounds (El-Shemy HA. Ed). 2011, pp 21-59. Intech publishing, Croatia.

14. Yoo SK, Cho WH, Kang SM, Lee SH. Isolation and identification of microorganisms in Korean traditional soybean paste and soybean sauce. Korean J Appl Microbiol Biotechnol. 1999,27: 113-117. 